\title{
LOGOPEDIAN KOULUTUS PUHETERAPEUTIN AMMATILLISEN TYÖN PERUSTANA
}

Puheterapeutteja koulutetaan Suomessa viiden yliopiston logopedian koulutusohjelmassa: Helsingin, Oulun, Tampereen ja Turun yliopistossa sekä Åbo Akademissa. Puheterapeutin pätevyyden antaa jossakin näistä yliopistoissa suoritettu maisterin tutkinto, jonka tieteenalana on ollut logopedia. Maisterin tutkinnon suoritettuaan henkilö voi hakea Valviran laillistusta, joka oikeuttaa hänet toimimaan terveydenhuollon ammattilaisena, puheterapeuttina.

Puheterapeutin työtehtävien suuri kirjo edellyttää työn tekijöiltä monipuolisia taitoja, joihin kaikkiin koulutuksen pitäisi antaa riittävät perusvalmiudet. Puheterapeutit tutkivat, arvioivat ja kuntouttavat ainakin sellaisia ihmisiä, lapsia ja aikuisia, joilla on vuorovaikutuksen, viestinnän, puheen, kielen moninaisten ilmiöiden tai äänen häiriöitä. Puheterapiatyön erityisalueita ovat lisäksi muun muassa syömisja nielemishäiriöt, puhetta tukevan ja korvaavan viestinnän ilmenemismuodot sekä monikielisyys ja -kulttuurisuus puheterapeutin muihin työtehtäviin liittyvinä ilmiöinä. Häiriöiden taustalla voi olla kehityksellisiä syitä, sellaisia kuin kielenkehityksen erityisvaikeudet, kuuloviat, kehitys- ja CP-vammat tai autismin kirjon muodot, tai häiriön on voinut aiheuttaa jokin tapaturma tai sairaus, aikuisväestöllä esimerkiksi aivoverenkiertohäiriö tai etenevä muistisairaus. Erityisesti meluisassa ympäristössä työtä tekevät ihmiset, esimerkiksi opettajat, voivat saada työperäisiä äänihäiriöitä, joiden helpottamiseen he tarvitsevat puheterapeutin apua.

Puheterapiassa vuorovaikutus ja kieli ovat paitsi työn kohteena myös sen välineinä. $\mathrm{Pu}-$ heterapeutti tekee usein työtään suorassa kontaktissa kuntoutusasiakkaidensa kanssa, mutta yksilökuntoutuskin sisältää yleensä paljon työskentelyä, ohjausta ja konsultointia, terapiassa olevan lapsen vanhempien ja päiväkodin tai koulun henkilöstön kanssa tai terapiassa olevan aikuisen omaisten kanssa. Lisäksi puheterapeutit tekevät lähes aina moniammatillista tiimityötä, usein monissakin terveydenhuollon ja sosiaalitoimen työryhmissä. Puheterapeutilta edellytetäänkin erittäin hyviä ja monipuolisia vuorovaikutustaitoja näiden erilaisten työtehtävien hoitamiseen.

Puheterapeuttikoulutuksen tulee antaa perusvalmiudet kaikkien edellä mainittujen alueiden kaikkien työtehtävien hoitamiseen. Vastavalmistuneen puheterapeutin voidaan siis edellyttää selviävän mistä tahansa puheterapeutin työtehtävästä, mutta hän ei voi vielä hallita syvällisesti kaikkia alueita. Ammattitaito syvenee ja laajenee karttuvan työkokemuksen, täydennyskoulutuksen ja työnohjauksen myötä. Täydennyskoulutus on tärkeää myös siksi, että logopedian alan tieto uusiutuu esimerkiksi kuntoutustutkimusten kehittymisen myötä nopeasti. Puheterapeutit 
käyvätkin ahkerasti täydennyskoulutuksessa sekä kotimaassa että ulkomailla. Erikoistumiskoulutusta puheterapeuteille on toistaiseksi järjestetty vähän, muutamia yksittäisiä kursseja 1900-luvun loppupuolella, lisensiaatintutkintoon johtanut yliopistollinen koulutus (lasten- ja aikuisneurologia erikoistumisaloina) vuosina 2004-2007 sekä eurooppalaiseen kliiniseen erikoistumiskoulutukseen (www. ecsf.eu) liittyvä kliininen erikoistumiskoulutusjakso puheen sujuvuuden alalta vuonna 2016-2017.

Puheterapeutit tekevät siis työssään yleensä tiivistä moniammatillista yhteistyötä erilaisten terveys-, sosiaali- ja opetusalan ammattilaisten kanssa. Tulevien puheterapeuttien koulutuskin on luonteeltaan hyvin monitieteistä ja sisältää logopedian ydinopintojen lisäksi ainakin psykologian, lääketieteen ja kielitieteiden opintoja, valinnaisina usein muitakin, erityisesti käyttäytymistieteiden alojen opintoja. Logopedian monitieteisyydestä konkreettisena esimerkkinä voidaan pitää myös sitä, että logopedian koulutusohjelma on sijoitettuna eri yliopistoissa erilaisiin tiedekuntiin: Helsingissä lääketieteelliseen, Oulussa humanistiseen, Tampereella ja Turussa yhteiskuntatieteelliseen sekä Åbo Akademissa humanististen tieteiden, psykologian ja teologian tiedekuntaan. Lisäksi logopedian tutkijat toimivat usein monitieteisissä tutkimusryhmissä yhdessä erityisesti lääkärien ja psykologien kanssa.

\section{Kaksivaiheinen tutkinto}

Kaikkien Suomen yliopistojen perustutkintorakenne on hyvin samanlainen ja noudattaa vuonna 1999 allekirjoitetun Bolognan julistuksen periaatteita, joiden avulla eurooppalaisen korkeakoulualueen koulutusjärjestelmät pyrittiin yhdistämään valtioiden välisen liikkuvuuden parantamiseksi. Bolognan prosessin mukainen tutkintorakenne muodostuu toisiaan seuraavista kandi-, maisteri- ja tohtoritutkinnoista (lukuun ottamatta lääketieteitä, joiden ammattipätevyyden antava suomalainen perustutkinto on lisensiaatin tutkinto). Puheterapeutin pätevyyteen vaaditaan mais- teritutkinto, mutta kaikki logopedian opiskelijatkin suorittavat ensin humanististen tieteiden kandidaatin ja sen jälkeen filosofian maisterin tutkinnon. Logopedian opiskelijat ovat hyvin motivoituneita ja sitoutuvat vahvasti opintoihinsa. Opintonsa keskeyttäneiden määrä on hyvin pieni, eli lähes kaikki logopedian opinnot aloittaneet myös valmistuvat maisteriksi logopedian tieteenalalta. Kandi- ja maisteriopintojen ohjeellinen kesto on $3+2$ vuotta, mutta käytännössä monet logopedian opiskelijat käyttävät opiskeluunsa hiukan pitemmän ajan, viisi ja puoli tai kuusikin vuotta.

Kaikkien yliopistollisten koulutusohjelmien tulee alasta riippumatta antaa tutkimukseen perustuvaa opetusta. Logopedian tutkimukseen perustuvaan opetukseen kuuluu tärkeänä osana opiskelijoiden perehdyttäminen näyttöön perustuviin kuntoutuskäytäntöihin (evidence-based practice). Tätä ajattelua pyritään kuljettamaan opintojen läpi punaisena lankana ja toivotaan, että näin tulevat puheterapeutit omaksuisivat myös kliiniseen työhönsä tutkimusnäyttöön perustuvan ajattelun. Muutenkin logopedian koulutusohjelmissa kytketään perusopinnoista alkaen teoreettiset ja kliiniset opinnot toisiinsa siten, että puheterapeutin työ perustuisi aina häiriöiden ja kuntoutuksen teoreettisten perusteiden ymmärtämiseen. Lisäksi logopedian opintoihin liittyvät metodiset opinnot liitetään teoreettisten ja kliinisten opintojen jatkumon osaksi.

Logopedian koulutusohjelmissa opintojen sisältö ja suoritustavat on yleensä määritelty hyvin tarkasti; valinnaisuutta ja kokonaan vapaita opintoja on vain vähän. Tällä on pyritty takaamaan, että jokaisella logopedian opiskelijalla on valmistuttuaan riittävät tiedot ja taidot hakeutua mille tahansa puheterapiatyön alueelle töihin ja myös vaihtaa toiselle alalle työuransa aikana. Logopedian opintojen lisäksi tutkintoon kuuluu pakollisena psykologian, lääketieteen ja kielitieteiden opintoja. Psykologiasta logopedian opiskelijat suorittavat perus- ja aineopintoja, joiden opintopistemäärä voi yksittäisellä opiskelijalla nousta jopa 45 pisteeseen, kun vapaavalintaiset psykologian opinnot lasketaan mukaan. Lääketieteen opintojen määrä on 15-20 opintopistettä yli- 
opistosta riippuen. Myös fonetiikan ja muiden kielitieteiden opintopistemäärä vaihtelee eri yliopistoissa jonkin verran.

\section{Kandiopinnot}

Ensimmäisen opiskeluvuoden aikana opiskelijat suorittavat yleensä kokonaisuudessaan logopedian perusopinnot, 25 opintopistettä. Perusopintojen vaiheessa opiskelijan on tarkoitus omaksua tieteenalansa peruskäsitteet ja luoda muutenkin kokonaiskuva opiskelemastaan aineesta. Tavoitteena on, että logopedian opiskelija oppii ymmärtämään, kuinka puhe, kieli ja viestintä kehittyvät ja kuinka puhe-elimistö normaalisti toimii. Opiskelija perehtyy myös logopedisen tutkimuksen keskeisiin kysymyksiin ja saa perusvalmiudet tieteelliseen lukemiseen ja kirjoittamiseen. Ensimmäisen ja viimeistään toisen opiskeluvuoden aikana logopedian opiskelijat suorittavat myös lääketieteen opintonsa, joiden tarjoama perusta on tarpeen logopedian aineopintojen monien opintojaksojen suorittamisessa. Lääketieteen opintoja suorittaessaan opiskelija oppii ymmärtämään, kuinka puheeseen, kieleen ja viestintään liittyvät logopediset ilmiöt linkittyvät lääketieteeseen ja sen osa-alueista erityisesti neurologiaan, psykiatriaan, korva-, nenä- ja kurkkutauteihin sekä foniatriaan ja audiologiaan, hiukan vaihtelevin painotuksin ja yhdistelmin eri yliopistoissa.

Toisena ja kolmantena opiskeluvuonna suoritetaan aineopinnot, joiden aikana logopedian opiskelijoiden on tarkoitus omaksua teoreettiset perustiedot kaikista keskeisistä puheterapiatyön alueista ja alkaa kehittää puheterapeutin käytännön taitojaan kliinisten harjoittelujaksojen avulla. He oppivat logopedisen diagnostiikan ja kuntoutuksen perusteet sekä harjaantuvat teoreettisten ja kliinisten ongelmien ratkaisemiseen. Aineopintoihin kuuluvaa kandidaatin tutkielmaa tehdessään logopedian opiskelija alkaa rakentaa oman tieteellisen työskentelynsä perusvalmiuksia.

Teoreettiset aineopinnot on eri yliopistoissa ryhmitelty hiukan erilaisiin ja eri tavoin nimettyihin kokonaisuuksiin. Niiden keskeistä sisältöä ovat moninaiset kielelliset häiriöt, joihin kuuluvat esimerkiksi lasten ja nuorten kehitykselliset kielelliset häiriöt, kirjoitetun kielen häiriöt, kuulovammoihin liittyvät kielelliset ilmiöt sekä afasiaan, eteneviin muistisairauksiin ja muihin aikuisiällä syntyneisiin tiloihin liittyvät kielen häiriöt. Muita aineopinnoissa käsiteltyjä häiriöalueita ovat esimerkiksi motoriset puhehäiriöt, puheen sujuvuuden ongelmat, syömis- ja nielemistoimintojen häiriöt, puhe-elinten rakenteellisista poikkeavuuksista johtuvat puheen ja äänen häiriöt sekä muut äänentuoton häiriöt. Lisäksi aineopinnoissa voi olla esimerkiksi monikielisyyteen ja -kulttuurisuuteen, puhetta tukevaan ja korvaavaan viestintään liittyviä sekä logopedisen arvioinnin teoreettisia lähtökohtia ja käytännön sovellusta koskevia opintojaksoja.

Aineopintojen kliinisissä opinnoissa opiskelijat perehtyvät puheterapeutin ammatillisen toiminnan ja ammattiroolissa toimimisen perusteisiin. He harjoittelevat puheterapeuttina toimimista kliinisillä harjoittelujaksoilla yksittäisten asiakkaiden tai pienten ryhmien kanssa laillistetun puheterapeutin ohjauksessa. Asiakkaina on sekä lapsia että aikuisia, joiden häiriödiagnoosit vaihtelevat.

Aineopintojen metodiopinnoissaan logopedian opiskelijat perehtyvät keskeisiin tieteellisiin tutkimusmetodeihin ja niiden soveltamiseen logopedisiin aineistoihin. Kandidaatin tutkielma on joissakin yliopistoissa kirjallisuuskatsaus, joissakin se taas perustuu pieneen empiiriseen tutkimusaineistoon.

Logopedian perus- ja aineopinnot, lääketieteen, psykologian ja kielitieteen pakolliset opinnot sekä kaikille yliopisto-opiskelijoille pakolliset yleisopinnot (esimerkiksi viestintäja kieliopinnot sekä tieto- ja viestintätekniikan opinnot) muodostavat logopedian opiskelijan humanististen tieteiden kandidaatin tutkinnon. Tämän tutkinnon suoritettuaan logopedian opiskelijat jatkavat suoraan syventäviin opintoihin, jotka suoritettuaan he saavat filosofian maisterin tutkintotodistuksen.

\section{Maisteri- ja jatko-opinnot}

Syventävissä opinnoissa logopedian opiskeli- 
ja oppii tarkastelemaan kriittisesti alan tutkimusta, suunnittelemaan ja toteuttamaan kuntoutusta sekä tuottamaan itse tietoa erilaisten teoreettisten ja kliinisten ongelmien ratkaisemiseksi. Opintoihin kuuluu logopedisen tutkimuksen erityiskysymyksiä tarkastelevia teoreettisia opintojaksoja, pro gradu -tutkielma ja sen tekemistä tukevia metodiopintoja sekä kliinisiä opintojaksoja, joista viimeinen on laajin, neljän kuukauden mittainen kokopäiväinen harjoittelu jossakin sellaisessa työpaikassa, jonka laillistettu puheterapeutti toimii opiskelijan harjoittelun ohjaajana. Pro gradu -tutkielmien pohjana on pääsääntöisesti pieni empiirinen tutkimus, joka perustuu joko tekijänsä itse keräämään tutkimusaineistoon tai logopedian opettajien tai tutkimusryhmien aineistoihin. Gradujen aiheiden kirjo on logopedian opintojen ja puheterapeutin työn moninaisten tehtävien tavoin laaja. Opinnäytetyön luonteestaan huolimatta logopedian gradut tuottavat usein hyödyllistä uutta tietoa sekä logopediselle tutkimukselle että erityisesti suomalaisen puheterapiatyön kentälle. Gradujen korkeasta tasosta ja niiden tuottaman tutkimustiedon kiinnostavuudesta kertoo sekin, että vuosittain monet logopedian graduntekijät työstävät, usein yhdessä ohjaajansa kanssa, gradun valmistuttua tutkimuksestaan vielä artikkelin puheterapeuttien ammatilliseen lehteen tai johonkin alan tieteelliseen julkaisuun tai esityksen tieteelliseen kongressiin tai seminaariin.

Suurin osa logopedian tieteenalaopiskelijoista tähtää opinnoillaan puheterapeutin pätevyyden antavaan maisterin tutkintoon. He näkevät logopedian koulutusohjelman ennen kaikkea ammattipätevyyden antavana koulutuksena. Logopedian tieteenalalta suoritettu maisterin tutkinto luo kuitenkin hyvän pohjan myös monenlaisiin muihin, erityisesti sosiaali- ja terveysalan hallinnon ja koulutuksen työtehtäviin, joihin edellytetään ylempää korkeakoulututkintoa. Lisäksi pieni osa logopediasta maisterin tutkinnon suorittaneista jatkaa jossain vaiheessa tutkijakoulutukseen, jonka tuloksena he suorittavat tohtorin tutkinnon logopedian alalta. Suurin osa näistä tutkijoista työllistyy nykyisellään yliopisto- jen logopedian yksiköihin opettaja-tutkijoiksi. Yliopiston opettajilta edellytetään tehtävänimikkeestä riippumatta pääsääntöisesti tohtorin tutkintoa. Tohtorin tutkintojen määrän mukaan arvioiden logopedia on tieteenalana vielä varsin nuori. Ensimmäiset puheterapeutin pätevyyteen johtavan koulutuksen aikaiset väitöskirjat valmistuivat vuonna 1996, ja reilun 20 vuoden aikana logopedian alan tohtorien määrä on kasvanut vähitellen noin viiteen kymmeneen. Suurin osa puheterapeuttitohtoreista on väitellyt logopedian oppiaineesta jossakin viidestä koulutuspaikasta, mutta suomalaisia puheterapeuttikoulutuksen saaneita henkilöitä on väitellyt myös ainakin lääketieteen, psykologian, fonetiikan, yleisen kielitieteen ja erityispedagogiikan aloilla. Tämä kuvastaa jälleen logopedia-tieteenalan monitieteisyyttä ja puheterapeuttien ammatin moniammatillisia kytkentöjä.

\section{Pyrkiminen ja valinnat}

Suomen viiteen logopedian koulutusyksikköön otetaan vuonna 2017 yhteensä 112 uutta opiskelijaa (Helsinki 25, Oulu 30, Tampere 15, Turku 28, Åbo 14). Suomenkielisillä yliopistoilla on yhteinen kirjallinen koe, joka pidetään samaan aikaan kaikissa paikoissa, mutta hakea voi vain yhteen yliopistoon. Turussa on kirjallisen kokeen lisäksi suullinen koe, johon osallistujat valitaan kirjallisessa kokeessa menestymisen perusteella. Åbo Akademilla on kokonaan oma valintakokeensa. Sekin on kaksiosainen ja sisältää kirjallisen kokeen lisäksi haastattelun (logopedian valinnoista tarkemmin ks. Opintopolku.fi).

Logopedia on valtakunnallisesti hyvin suosittu hakukohde. Hakijoiden ja valittujen suhteellisia määriä tarkasteltaessa voidaan todeta, että logopediaa on usein vaikeampi päästä opiskelemaan kuin esimerkiksi vaikeana hakukohteena pidettyä lääketiedettä. Logopedian suosiota selittää logopedian alan ja puheterapeutin ammatin yleisen kiinnostavuuden ja monipuolisesti haastavan luonteen lisäksi se, että puheterapeutiksi valmistuva henkilö työllistyy lähes varmasti. Puheterapeuttien tarve on suuri koko maassa, ja isoimpia kaupunke- 
ja lukuun ottamatta monilla seuduilla puheterapeuteista on suoranaista pulaa. Tilanne on jatkunut pitkään, eikä sitä ratkaissut kolmen uuden opiskelupaikan, Tampereen ja Turun yliopiston sekä Åbo Akademin, koulutuksen käynnistäminen vuonna 2005, koska samoihin aikoihin puheterapeuttien nuorehkon ammattikunnan vanhimpien edustajien eläköityminen alkoi vähentää työntekijöitä työuran toisesta päästä.

Puheterapeuttipulasta keskusteltaessa ihmetellään usein nykyisten koulutuspaikkojen pieniä opiskelijakiintiöitä ja ehdotetaan ratkaisuksi sisään otettavien uusien opiskelijoiden määrän kasvattamista. Koulutuspaikatkin tuntevat hyvin aloituspaikkojen lisäämisen tarpeen ja paineen, mutta nykyisillä opettajamäärillä lisääminen ei ole mahdollista, vaan opiskelijamäärien kasvattaminen edellyttäisi myös selvää henkilökuntaresurssien lisäystä.

\section{Yliopistojen yksilölliset profiilit}

Koska kaikissa logopedian viidessä koulutusyksikössä suoritetun logopedian kandi- ja maisteritutkinnon tulee antaa yhtäläinen puheterapeutin pätevyys, koulutusyksiköt tekevät tiivistä yhteistyötä riittävän samansisältöisen ja laadukkaan koulutuksen takaamiseksi. Tätä ja muita yhteistyötarpeita varten on luotu valtakunnallinen Logonet-verkosto, jonka virallinen yhteistyösopimus allekirjoitettiin syksyllä 2009. Logonetin johtoryhmä kokoontuu vähintään kaksi kertaa vuodessa, ja eräänä sen keskeisenä tehtävänä voidaan pitää juuri suomalaisen logopedian opetuksen laadun valvomista ja kehittämistä.

Logopedian monialaisen koulutuksen kehittämisen kannalta on kuitenkin eduksi myös se, että kaikki viisi yliopistoyksikköä eivät kouluta ja tutki aivan samalla tavalla ja samoja asioita, vaan että kukin luo myös omaa profiiliaan. Kun eri paikoissa syvennetään logopedista tietoa ainakin jossain määrin eri aloilta, valtakunnallisesti yhdessä tuotettu uusi ja ajantasainen tutkimustieto on laajempaa ja rikkaampaa kuin jos jokainen yksikkö pyrkisi tutkimaan ja kehittämään samoja logopedian aloja.
Helsingin yliopiston logopedian koulutusyksikkö on Suomen vanhin. Sen alku voidaan ajoittaa vuoteen 1947, jolloin fonetiikan oppiaine jaettiin virallisesti kahteen linjaan: kielitieteellis-akustiseen sekä puhe- ja äänifysiologiseen. Jo sitä ennen, ainakin 1930-luvulta lähtien, fonetiikassa oli mahdollista opiskella joko yleisen linjan tai kuuromykkäinopettajan koulutuslinjan mukaan, joten suomalaisen puheterapeuttikoulutuksen varhaisimmat juuret voidaan ajoittaa jo lähes sadan vuoden taakse. Vuoteen 2003 asti Helsingin yliopiston logopedia kuului humanistiseen tiedekuntaan ja sen jälkeen vuoden 2016 loppuun käyttäytymistieteelliseen tiedekuntaan. Vuoden 2017 alussa se siirtyi yhdessä psykologian koulutuksen kanssa lääketieteelliseen tiedekuntaan, johon näin on keskitetty merkittävä osa Helsingin yliopiston terveydenhuollon ammatteihin pätevöittävistä koulutuksista. Samalla myös logopedian tutkijoille syntyy entistä paremmat mahdollisuudet liittyä esimerkiksi korkeatasoista aivotutkimusta tekeviin monitieteisiin tutkimusryhmiin. Helsingin yliopiston logopedia on määritellyt keskeisiksi tutkimuskohteikseen vuorovaikutuksen, kuntoutuksen sekä puheen, kielen ja viestinnän ja niiden häiriöt. Tutkimuksen erityisaloina voidaan mainita keskosena syntyneiden lasten kielen kehitys, aikuisneurologiset kielen ja viestinnän häiriöt, mukaan lukien ikääntymiseen ja muistisairauksiin liittyvät kysymykset, sekä puhetta tukevaan ja korvaavaan viestintään liittyvä problematiikka.

Oulun yliopiston logopedian koulutus alkoi vuonna 1981. Logopedian tutkinto-ohjelma on kuulunut alusta asti humanistiseen tiedekuntaan. Oulun yliopiston logopedian tutkimusyksikössä on toiminut vuodesta 2009 lähtien Lapsenkielen tutkimuskeskus (www. ouluclrc.fi). Niinpä Oulussa tehtävä tutkimus painottuukin pitkälti lasten puheen ja kielen kehityksen ja sen häiriöiden tutkimiseen. Tutkimuskeskuksella on neljä tutkimuksen painopistealuetta: 1) tyypillisen, viivästyneen ja poikkeavan puheen- ja kielenkehityksen erotusdiagnostiikka, 2) ennenaikaisina ja pienipainoisina syntyneiden lasten puheen ja kielen kehitys sekä oppiminen, 3) auditiivinen 
puheen prosessointi ja kuulovikaisten lasten puhutun kielen kehitys ja 4) pragmaattinen kehitys ja sen häiriöt. Tutkimusta toteutetaan monitieteisissä tutkimusryhmissä. Varsinaisten tutkimushankkeiden lisäksi keskuksessa tehdään myös aktiivista arviointi- ja testimenetelmien kehitystyötä.

Tampereen yliopiston logopedian koulutus käynnistyi vuonna 2005 humanistisessa tiedekunnassa. Yliopiston lukuisten rakennemuutosten jälkeen logopedia on yhteiskuntatieteellisen tiedekunnan hyvinvointitieteitä yhdessä psykologian ja sosiaalityön tutkimuksen kanssa. Nämä kolme tutkinto-ohjelmaa tekevät yhteistyötä erityisesti asiakastyön taitojen opetuksessa. Tampereen yliopiston logopedian tutkimuksella on kaksi pääsuuntaa: ääniergonomia ja neurologopedia. Näissä on kehitetty arviointimenetelmiä, kuten luokkahuoneiden ääniergonomiakartoitus ja eri-ikäisten puhujien kertovan kielenkäytön mittarit. Tampereen neurologopedisessa tutkimuksessa korostuu laadullinen kielitieteellinen tarkastelu, erityisesti eri-ikäisten ihmisten kertovan kielenkäytön tavanomaisten ja poikkeavien piirteiden kuvailu.

Turun yliopiston logopedian koulutusohjelma on aloittanut niin ikään vuonna 2005 ja kuuluu yhteiskuntatieteelliseen tiedekuntaan muodostaen psykologian kanssa yhteisen laitoksen. Opetus- ja tutkimusyhteistyö psykologian oppiaineen kanssa on erityisen tunnusomaista Turun yliopiston logopedian toiminnalle. Teoriaopetuksen lisäksi tiivis yhteistyö näkyy kliinisten opintojen osa-alueella. Esimerkiksi moniammatillisessa klinikkatoiminnassa logopedian opiskelijat yhdessä psykologian, sosiaalityön sekä lääke- ja terveystieteen opiskelijoiden kanssa arvioivat klinikalle tulevia asiakkaita. Turun yliopiston logopedian tutkimus on profiloitunut ja sitoutunut vahvasti neurokognitiiviseen ja kokeelliseen tutkimussuuntaukseen sekä monikielisyyden ja monikulttuurisuuden tutkimukseen. Lisäksi sen tutkimusalueen piiriin kuuluu erilaisten arviointimenetelmien kehittämistä sekä aikuisille että lapsille.
Åbo Akademissa logopedian koulutusohjelma (utbildningslinjen för logopedi) käynnistyi samoin vuonna 2005, ja se kuuluu humanististen tieteiden, psykologian ja teologian tiedekuntaan. Åbo Akademi on Suomen ruotsinkielinen yliopisto, joten opetus annetaan pääasiassa ruotsin kielellä. Syventävien opintojen vaiheessa opetusta annetaan jonkin verran myös englannin kielellä. Opiskelijat ovat äidinkieleltään ruotsinkielisiä tai kaksikielisiä (suomi-ruotsi). Tutkimuksen painopiste on äänihäiriöiden tutkimisessa, mikä näkyy myös kurssitarjonnassa. Äänihäiriökurssit ovat laajempia kuin muiden yliopistojen koulutusohjelmissa. Muita tutkimusalueita ovat kaksikielisyys ja aikuisneurologisiin kommunikointihäiriöihin liittyvä kuntoutus.

Kaisa Launonen, professori, Helsingin yliopisto

Eira Jansson-Verkasalo, professori, Turun yliopisto

Anna-Maija Korpijaakko-Huuhka, professori, Tampereen yliopisto

Sari Kunnari, professori, Oulun yliopisto

Pirkko Rautakoski, professori, Åbo Akademi 